\title{
Nontoxigenic Strains of Pseudomonas syringae pv. phaseolicola Are a Main Cause of Halo Blight of Beans in Spain and Escape Current Detection Methods
}

\author{
Arantza Rico, Ruth López, Carmen Asensio, M. Teresa Aizpún, M. Carmen Asensio-S.-Manzanera, and Jesús Murillo
}

First, fourth, and sixth authors: Laboratorio de Patología Vegetal, Departamento de Producción Agraria, ETS Ingenieros Agrónomos, Universidad Pública de Navarra, 31006 Pamplona, Spain; and second, third, and fifth authors: Servicio de Investigación y Tecnología Agraria, Consejería de Agricultura y Ganadería, Junta de Castilla y León, 47080 Valladolid, Spain. Accepted for publication 9 July 2003.

\begin{abstract}
Rico, A., López, R., Asensio, C., Aizpún, M. T., Asensio-S.-Manzanera, M. C., and Murillo, J. 2003. Nontoxigenic strains of Pseudomonas syringae pv. phaseolicola are a main cause of halo blight of beans in Spain and escape current detection methods. Phytopathology 93:15531559 .

From a collection of 152 pseudomonads isolated from diseased beans in Spain, $138(91 \%)$ of the strains were identified as Pseudomonas syringae pv. phaseolicola and the rest as $P$. syringae pv. syringae. The $P$. syringae pv. phaseolicola strains produced typical water-soaked lesions on bean pods, although 95 of them did not produce phaseolotoxin in vitro. Ninety-four of these isolates did not produce the expected $0.5-\mathrm{kb}$ product after polymerase chain reaction (PCR) amplification using primers specific for open reading frame (ORF) 6 of the phaseolotoxin (tox) gene cluster and did not contain DNA homologous to ORF 6 in

Southern hybridization experiments. To our knowledge, this is the first report of the widespread occurrence in the field of strains of $P$. syringae pv. phaseolicola lacking the tox cluster, which contrasts sharply with the general belief that Tox $^{+}$isolates are the only ones with epidemiological importance. Additionally, the tox- isolates were not specifically detected by a commercial polyclonal antisera in an enzyme-linked immunosorbent assay. Accordingly, it is possible that the certification of seed lots as free of the pathogen cannot be reliably done in Spain, or in any other country where tox $x^{-}$strains might occur frequently, using current PCR or serological protocols. The amplification of three avirulence genes by PCR allowed us to make predictions of the $P$. syringae pv. phaseolicola race structure, as confirmed by plant assays. Six races (races 1, 2, 5, 6, 7, and 9) were identified, with race 7 being the most prevalent $(46.1 \%)$ followed by races $6(21.3 \%)$ and $1(9.0 \%)$. All the tox- isolates contained gene avrPphF, typical of races $1,5,7$, and 9 .
\end{abstract}

The three major bacterial diseases of common bean (Phaseolus vulgaris L.) are caused by pathovars of Pseudomonas syringae and Xanthomonas campestris and result in economically important losses worldwide $(31,41)$. In particular, $P$. syringae pv. phaseolicola, causing halo blight, is probably the most important bacterial pathogen of bean in Europe, the United States, and many other countries. Spain is not an exception. Some of these pathogens cause field epidemics $(1,4,41)$. $P$. syringae pv. phaseolicola was first described in Spain in 1939 and it also appears to be the main cause of bacterioses of bean, although $P$. syringae pv. syringae was reported to be of local importance in certain areas and bean cultivars $(4,7)$. Although it is still considered a quarantine organism in Spain, X. campestris pv. phaseoli has been repeatedly isolated in the field $(1,4 ; \mathrm{C}$. Asensio, unpublished data) and works are in progress to determine its importance for bean production.

Control of halo blight is difficult, and the only practical methods for its management are the use of pathogen-free seed and appropriate cultural practices and planting of resistant cultivars. The presence of extremely low levels of primary inoculum can initiate severe epidemics under favorable conditions, and in consequence, certification of seed as free of the pathogen requires the use of highly sensitive and specific methods. Detection and identification of $P$. syringae pv. phaseolicola has been done using different methods that include microbiological assays (15), nucleic

Corresponding author: J. Murillo; E-mail address: jesus@unavarra.es

Publication no. P-2003-1020-01R

(C) 2003 The American Phytopathological Society acid hybridization (36), and different serological methods $(44,51)$, for which there are a number of commercially available antibodies. However, due to its effectiveness and low cost, several researchers have developed detection assays based on the amplification of specific DNA sequences by means of polymerase chain reaction (PCR) $(2,28,37)$. Further, rapid-cycle, real-time PCR is currently being evaluated as a routine tool for the diagnosis of $P$. syringae pv. phaseolicola in bean seed (38). In all these cases, specific primers were designed from the available sequence of DNA coding for phaseolotoxin biosynthesis, which is organized as a large $(>30 \mathrm{~kb})$ gene cluster (tox cluster) $(11,54)$. Phaseolotoxin is a non-host-specific toxin that induces chlorosis on leaves of several plant species by inhibition of ornithine carbamoyl transferase, a critical enzyme in the urea cycle. Toxin production is very specific to $P$. syringae pv. phaseolicola, although it also was described in a single bean isolate of $P$. syringae pv. syringae and in $P$. syringae pv. actinidiae, which causes a canker disease of kiwifruit $(28,43,47)$. Nontoxigenic $\left(\mathrm{Tox}^{-}\right)$strains of $P$. syringae $\mathrm{pv}$. phaseolicola have been described, and it is known that they are still pathogenic and occasionally occur in the field (17), although it is generally believed that Tox ${ }^{-}$strains are of little or no epidemiological significance $(30,31,37)$.

Based on their interaction with eight bean differential cultivars, nine races of $P$. syringae pv. phaseolicola have been differentiated involving five pairs of matching resistance-avirulence genes (Table 1) $(45,49)$. Three of these avirulence (avr) genes ( $a v r P p h B$, avrPphE, and $a v r P p h F)$ were cloned and sequenced $(16,42,48)$. Although $a v r P p h B$ and $a v r P p h F$ are present only in races expressing the corresponding phenotype, avrPphE is present in all the examined isolates but is only functional as an $a v r$ gene in races $2,4,5$, and 7 . The geographical distribution of races is not 
random, and races 3, 4, 5, 8, and 9 are not found, or only rarely, outside of Africa, whereas races 1, 2, 6, and 7 are distributed worldwide (45). Race 6 , which is compatible with all the differential cultivars (Table 1), appears to be on average the predominant race worldwide $(19,20,45)$, but race 8 is by far the most common in South Africa (5). Therefore, it is necessary to know beforehand the race structure of the pathogen in a given area, and to continuously monitor any possible deviations, in order to implement effective control measures based on the deployment of vertical resistance.

In the County of Castilla y León, the largest dry bean producing region in Spain, most of the bean crop is dedicated to high quality common bean landraces that are, in general, highly susceptible to bacterioses. Consequently, frequent disease outbreaks are a major constraint for bean production and cause the disappearance of valuable local bean cultivars (1). Ongoing breeding programs at Servicio de Investigación y Tecnología Agraria (directed by C. Asensio) aim to introduce durable resistance to these local bean genotypes. In this work, we focused on the identification and characterization of the local Pseudomonas populations in order to support the breeding programs and to develop appropriate molecular tools for the rapid identification of races. Our results demonstrate the prevalence in Spanish fields of nontoxigenic $P$. syringae pv. phaseolicola, which cannot be detected by PCR or enzymelinked immunosorbent assay (ELISA) using the currently available methods. A preliminary report has been published (29).

\section{MATERIALS AND METHODS}

Strains and growth conditions. Reference strains of bacteria and fungi were obtained from international collections and are listed in Table 2. Unless otherwise indicated, $P$. syringae isolates were propagated on King's medium B (KMB) $(18)$ at $28^{\circ} \mathrm{C}$.

Isolation and identification of bacteria from diseased beans. Bacteria were isolated on KMB following standard methods (21) from bean leaves or pods with typical symptoms of bacterioses. From the original isolation plates, only fluorescent colonies were retained for this work. All isolates were purified by a series of single colony transfers on $\mathrm{KMB}$ and stored at $-80^{\circ} \mathrm{C}$ in $\mathrm{KMB}$ plus $20 \%$ glycerol before their characterization.

Bacterial isolates were identified essentially as described (21, 39) following the LOPAT scheme (levan production, oxidase activity, potato soft rot, arginine dihydrolase activity, and tobacco hypersensitive response) (21), except that the degradation of potato tissue was not examined and the arginine dihydrolase test was carried out on petri dishes using anaerobic jars (3). We examined the utilization of diverse carbohydrates as the sole carbon source, the degradation of aesculine, degradation of casein on milk-Tween (MT) medium (8), production of toxins, and pathogenic characteristics. Carbohydrates (D-mannitol, inositol, D-sorbitol, erythritol, L+tartrate, D+tartrate, and L-lactate) were added to Ayer's minimal medium (21) to a final concentration of $0.1 \%$ (wt/vol). Those isolates that did not show significant growth after 1 week of incubation at $28^{\circ} \mathrm{C}$ were considered negatives.

Symptomatology on pods and leaves of bean cv. Canadian Wonder, which is susceptible to all known races of $P$. syringae pv. phaseolicola, was examined as described $(10,45)$. Excised pods were dipped in $70 \%$ ethanol, rinsed two times in distilled water, and inoculated with a toothpick. To confirm the pathogenicity of the isolates, the symptomatology on leaves of cv. Canadian Wonder was examined as described below for race identification. At least two replicate inoculations were made per isolate.

Toxin production. The production of antimetabolite toxins and phytotoxins was examined following previously published procedures $(6,9)$ with slight modifications (3). For phaseolotoxin, the isolates were toothpick-inoculated on top of a lawn of Escherichia coli on solid Ayer's minimal medium (21) and incubated for 2 days at $22^{\circ} \mathrm{C}$. To confirm the identity of the toxins, isolates also were tested on plates supplemented with $100 \mu \mathrm{l}$ of a sterile $1 \%$ (wt/vol) solution of the amino acids L-ornithine, L-citrulline, and $\mathrm{L}$-arginine. Isolates were considered to produce phaseolotoxin when the inhibition of $E$. coli growth was inverted on plates containing L-citrulline and L-arginine but not on plates with Lornithine. The production of syringomycin was assessed by the capacity of the isolates to inhibit the growth of Geotrichum candidum F260 on potato dextrose agar plates (9).

Serology. Double-antibody sandwich (DAS)-ELISAs were performed with a commercial kit (Loewe Biochemica $\mathrm{GmbH}$, Germany) and following the manufacturer's instructions. Bacterial suspensions were prepared on buffered physiological saline (140 mM NaCl, $2 \mathrm{mM} \mathrm{NaH} \mathrm{PO}_{4}$, and $15 \mathrm{mM} \mathrm{Na}_{2} \mathrm{HPO}_{4}$ ) and adjusted to optical density (OD) at $600 \mathrm{~nm}$ of approximately 1 before applying them to antibody-coated plates. In every plate, $P$. syringae pv. phaseolicola strain 1449B was used as a positive control and $P$. syringae pv. syringae strains $\mathrm{B} 728 \mathrm{a}$ and $\mathrm{B} 86-17$ as negative controls. The results were read on a plate reader (Multiskan EX; Thermo Electron, Finland) at $405 \mathrm{~nm}$. In order to make comparisons among plates, we calculated the serological reaction (SR) for each isolate as described (40), using the formula SR = $[(x-y) /(z-y)] \times 100$, where $x$ is the average OD for the studied isolate, $z$ is the average OD for the positive control, and $y$ is the average OD for the negative controls. Results were considered negative when the SR was below 50. Strains were tested in at least two separate experiments with two replicates each.

TABLE 1. Partly validated model to explain observed interactions between races of Pseudomonas syringae pv. phaseolicola and cultivars of the host, bean

\begin{tabular}{|c|c|c|c|c|c|c|c|c|c|c|c|c|c|c|}
\hline & & & & & & & & & & ace/avr gen & & & & \\
\hline & & & & & & 1 & 2 & 3 & 4 & 5 & 6 & 7 & 8 & 9 \\
\hline & & & & & & avrPphF & $\cdot$ & $\cdot$ & $\cdot$ & avrPphF & $\cdot$ & avrPphF & $\cdot$ & avrPphF \\
\hline & & & & & & $\cdot$ & avrPphE & $\cdot$ & avrPphE & avrPphE & $\cdot$ & avrPphE & - & - \\
\hline & & & & & & $\cdot$ & $\cdot$ & avrPphB & $a v r P p h B$ & $\cdot$ & $\cdot$ & - & - & - \\
\hline & & & & & & - & - & - & - & 4 & - & - & - & - \\
\hline Cultivar & & Res & $\operatorname{tanc}$ & ene & & $\cdot$ & 5 & $\cdot$ & $\cdot$ & - & - & • & 5 & 5 \\
\hline Canadian Wonder & $\cdot$ & $\cdot$ & - & $\cdot$ & - & + & + & + & + & + & + & + & + & + \\
\hline A52 (ZAA54) & $\cdot$ & • & $\cdot$ & 4 & • & + & + & + & + & - & + & + & + & + \\
\hline Tendergreen & $\cdot$ & $\cdot$ & $R 3$ & $\cdot$ & - & + & + & - & - & + & + & + & + & + \\
\hline Red Mexican U13 & $R 1$ & $\cdot$ & • & 4 & - & - & + & + & + & - & + & - & + & - \\
\hline 1072 & $\cdot$ & $R 2$ & $\cdot$ & $\cdot$ & - & + & - & + & - & - & + & - & + & + \\
\hline A53 (ZAA55) & • & $\cdot$ & $R 3$ & 4 & • & + & + & - & - & - & + & + & + & + \\
\hline A43 (ZAA12) & $\cdot$ & $R 2$ & $R 3$ & 4 & 5 & + & - & - & - & - & + & - & - & - \\
\hline Guatemala 196-B & $R 1$ & $\cdot$ & $R 3$ & 4 & • & - & + & - & - & - & + & - & + & - \\
\hline
\end{tabular}

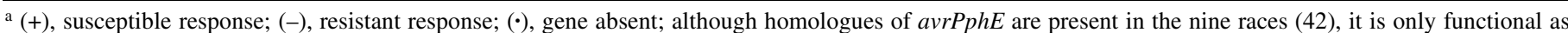
an avirulence gene in the races indicated. Avirulence/resistance matching genes: $a v r P p h F / R 1 ; a v r P p h E / R 2$; and $a v r P p h B / R 3$ (adapted from literature citation 49). 
Molecular genetic techniques. PCR amplifications were performed in a total volume of $25 \mu \mathrm{l}$ by mixing $20 \mathrm{pmol}$ each primer, $0.15 \mathrm{mM}$ each dNTP, $1 \times$ PCR reaction buffer, $1.5 \mathrm{mM} \mathrm{MgCl}$, 1 unit of Taq DNA polymerase (Biotaq; Bioline Ltd., London), and $5 \mu \mathrm{l}$ of a bacterial cell suspension. Specific primers for the amplification of the ethylene forming enzyme gene (efe) (34), the coronafacate ligase gene from the coronatine cluster (22), avrPphB (42), avrPphE (42), avrPphF (48), open reading frame (ORF) 6 from locus $p h t E$ of the phaseolotoxin biosynthesis cluster (primers P 5.1 and P 3.1) (37,54), and virPphA (14) were as published previously. Amplifications were carried out using a RoboCycler Gradient Cycler (Stratagene, La Jolla, CA) and consisted of a denaturation step of $10 \mathrm{~min}$ at $94^{\circ} \mathrm{C}$ followed by 30 cycles at $94^{\circ} \mathrm{C}$ for $1 \mathrm{~min}, 55^{\circ} \mathrm{C}$ for $1 \mathrm{~min}$, and $72^{\circ} \mathrm{C}$ for $1 \mathrm{~min}$, and a final extension step at $72^{\circ} \mathrm{C}$ for $10 \mathrm{~min}$.

DNA was isolated from single colonies grown overnight in KMB with a DNA extraction kit (Puregene; Gentra Systems Inc., Minneapolis, MN). Southern transfer was done by a standard procedure (33), and hybridization of nylon filters was carried out with a chemiluminescence labeling and detection kit (Roche Diagnostics, Basel, Switzerland). Appropriate amplicons to be used as DNA probes were purified from gels and ligated to pGemT-Easy (Promega, Madison, WI); the identity of the cloned inserts was routinely confirmed by DNA sequencing. To label the probe, the fragment was amplified from the clone, purified from a $1 \%$ agarose gel, and labeled by random priming.

Sequencing and analysis of gyrB and $r p o D$. Primer pairs gyrB-L (5'-AAGTATCCGGCGGCTTG-3') and gyrB-R (5'-GTGGTCGCGACCTTGTG-3') and rpoD-L (5'-CGCCAAACGTATCGAAGAA-3') and rpoD-R (5'-GCTATTTTCAGGCCGGTTT$3^{\prime}$ ) were designed from published sequences of $\mathrm{gyrB}$ (EMBL Accession No. AB016375 [35]) and $r p o D$ (EMBL Accession No. AB039500 [53]), respectively, from strains of $P$. syringae pv. phaseolicola. Genes gyrB and $r p o D$ were amplified as described previously from the nontoxigenic $P$. syringae pv. phaseolicola strains CYL233, CYL275, CYL309, CYL314, CYL325, and CYL352. Partial sequences of 534 and 572 nucleotides were determined at MWG-Biotech AG (Ebersberg, Germany) directly from the purified gyrB and $r p o D$ PCR fragments, respectively, using the corresponding amplification primers. Sequences were combined for the same strain and treated as a single 1106 nucleotide sequence, assuming that analysis using longer sequences results in better resolution and reliability (53). Sequences were aligned with the corresponding combined sequence fragments of a range of $P$. syringae pathovars and other pseudomonads (53) using ClustalW (46). Phylogenetic trees were constructed with ClustalW using the neighbor-joining method (32). The nucleotide sequences were deposited in the nucleotide sequence database as EMBL Accession Nos. AJ564779 to AJ564784 for gyrB and AJ564785 to AJ564790 for $r p o D$.

Race identification of $P$. syringae pv. phaseolicola strains. Isolates were inoculated on primary leaves of line 1072 of $P$. acutifolious of bean cvs. Canadian Wonder, A52, Tendergreen, Red Mexican UI3, A53, A43, and Guatemala 196-B as described previously (45). Infection was scored according to a previously defined five-point scale (12). At least six replicate plants were inoculated for each combination of isolate and cultivar.

\section{RESULTS}

Isolation and identification of $P$. syringae from diseased beans. Sampling was carried out from 1993 to 2001 in commercial fields over the entire bean production zone $(4,162$ ha in 1998) from Castilla y León County $\left(94,147 \mathrm{~km}^{2}\right)$, Spain, mainly from common bean landraces. From our own experience, these cultivars are highly susceptible to bacterioses in the field, although it is not known if they display resistance to any particular race of $P$. syringae. Bacteria were isolated from leaves and pods showing necrotic or water-soaked lesions typical of bacterioses, either surrounded or not by chlorotic haloes, and only fluorescent isolates were kept for further characterization. The 152 isolates examined in this work were fluorescent on $\mathrm{KMB}$, levan positive, oxidase and arginine dihydrolase negative, and elicited a hypersensitive reaction on tobacco (LOPAT group Ia), and were therefore considered $P$. syringae (21).

Fourteen of the isolates $(9.2 \%)$ displayed a biochemical pattern typical of $P$. syringae pv. syringae, produced syringomycins but not phaseolotoxin, and induced sunken brown lesions upon inoculation onto pods of bean cv. Canadian Wonder (Table 3). These isolates were in consequence identified as $P$. syringae pv. syringae and were not further characterized.

The remaining 138 isolates $(90.8 \%)$ were considered $P$. syringae pv. phaseolicola because they showed typical metabolic characteristics of this pathovar and their inoculation onto pods of universally susceptible cv. Canadian Wonder resulted in typical water-soaked lesions 2 to 3 days after inoculation (Table 3). Additionally, all of them produced specific amplification bands by PCR using primers specific for virPphA, shown to be essential for pathogenicity on beans (13), and for avrPphE. These isolates did not produce syringomycins and did not produce amplification bands with primers specific for coronatine genes and for the ethylene forming enzyme (Table 3), which has been described in $P$. syringae pv. glycinea and in kudzu isolates of $P$. syringae pv. phaseolicola (52). Assimilation of mannitol is usually negative for $P$. syringae pv. phaseolicola, although all the isolates from kudzu tested positive, as did some isolates from other hosts, including bean $(23,50)$. However, $72 \%$ of the Spanish isolates were able to utilize mannitol as the sole carbon source (Table 3). Noticeably, the 94 isolates that lacked the phaseolotoxin gene ORF 6 (tox ${ }^{-}$; described below) tested positive, whereas 38 of the 44 isolates containing ORF 6 tested negative as expected.

Phaseolotoxin detection. Unexpectedly, only 43 of the $P$. syringae pv. phaseolicola isolates produced phaseolotoxin (Table 3 ), as determined by the E. coli inhibition bioassay. The remaining 95 isolates $(68.8 \%)$ did not cause the inhibition of $E$. coli or, if they did, it was not specifically reverted by citrulline or arginine.

TABLE 2. Reference bacterial strains and fungi used in this study

\begin{tabular}{|c|c|c|}
\hline Strain & Characteristics & Source or reference \\
\hline \multicolumn{3}{|c|}{ Escherichia coli } \\
\hline СЕСТ831 & Sensitive to phaseolotoxin & $\begin{array}{c}\text { Colección Española } \\
\text { de Cultivos Tipo, } \\
\text { Spain }\end{array}$ \\
\hline \multicolumn{3}{|c|}{ Geotrichum candidum } \\
\hline F260 & Sensitive to syringomycin & A. de Vicente \\
\hline \multicolumn{3}{|c|}{$\begin{array}{l}\text { Pseudomonas syringae } \\
\text { pv. glycinea }\end{array}$} \\
\hline $49 \mathrm{a} / 90$ & $\begin{array}{l}\text { Race 4; coronatine pro- } \\
\text { ducer; } 1990, \text { Germany }\end{array}$ & M. Ullrich \\
\hline 4180 & $\begin{array}{l}\text { Race 4; coronatine pro- } \\
\text { ducer; } 1975, \text { New Zealand }\end{array}$ & $(24)$ \\
\hline \multicolumn{3}{|c|}{ pv. phaseolicola } \\
\hline $1281 \mathrm{~A}$ & Race $1 ; 1984, \mathrm{UK}$ & $(45)$ \\
\hline 882 & Race $2 ; 1975$, USA & $(45)$ \\
\hline $1310 \mathrm{~A}$ & Race $3 ; 1984$, Tanzania & $(45)$ \\
\hline $1302 \mathrm{~A}$ & Race 4; 1984, Rwanda & (45) \\
\hline $1375 \mathrm{~A}$ & Race 5; 1985, Kenya & $(45)$ \\
\hline 1299A & Race 6; 1984, Tanzania & $(45)$ \\
\hline 1449B & Race 7; 1985, Ethiopia & $(45)$ \\
\hline $2656 \mathrm{~A}$ & Race 8; 1990, Lesotho & $(45)$ \\
\hline 2709A & Race 9; 1990, Malawi & $(45)$ \\
\hline \multicolumn{3}{|l|}{ pv. syringae } \\
\hline B728a & $\begin{array}{l}\text { Wild type; Rif'; isolated from } \\
\text { Phaseolus vulgaris, USA }\end{array}$ & G. W. Sundin \\
\hline B86-17 & $\begin{array}{l}\text { Wild type; isolated from } \\
\text { Phaseolus vulgaris, USA }\end{array}$ & G. W. Sundin \\
\hline \multicolumn{3}{|l|}{ pv. tabaci } \\
\hline CFBP1621 & Wild type & C. Manceau \\
\hline
\end{tabular}


Other researchers have described the natural existence of Tox ${ }^{-}$ strains of $P$. syringae pv. phaseolicola $(24,37,50)$ as resulting either from point mutations or, apparently less frequently, from the absence of part or all of the tox cluster. However, although they are still pathogenic and occasionally occur in the field (17), it is generally believed that $\operatorname{Tox}^{-}$strains are of little or no epidemiological significance $(30,31,37)$. This is the basis for the widespread use of DNA sequences from the tox cluster as a target for the detection, by PCR or DNA hybridization, of P. syringae pv. phaseolicola in seed lots $(2,28,36,37)$. Accordingly, we examined if the Tox ${ }^{-}$isolates identified here could be detected by PCR using primers $\mathrm{P} 5.1$ and $\mathrm{P}$ 3.1, which are specific for phaseolotoxin genes and were designed for a highly sensitive enrichment PCR assay, BIO-PCR, for seed sample processing (37). All the Tox ${ }^{+}$ and one of the Tox ${ }^{-}$isolates produced the expected $0.5-\mathrm{kb}$ band after PCR amplification (Table 3; Fig. 1). The remaining 94 Tox $^{-}$ $P$. syringae pv. phaseolicola isolates, as well as isolates from pathovars glycinea, syringae, and tabaci, did not produce any amplification band or occasionally produced some nonspecific weak bands of higher size than expected. Southern hybridization experiments of genomic DNA using the P 5.1-P 3.1 amplicon from strain $1449 \mathrm{~B}$ as a probe showed that these latter isolates did not contain sequences homologous to the probe (Fig. 1). This suggests that the majority of the $\operatorname{Tox}^{-} P$. syringae pv. phaseolicola isolates native to Spain examined here might lack part of or the entire phaseolotoxin biosynthesis cluster and, in consequence, might remain undetected after PCR examination of contaminated seed lots.

Because Tox ${ }^{-}$isolates of $P$. syringae pv. phaseolicola are only rarely reported $(30,37,50)$, it is arguable that the Spanish nontoxigenic isolates lacking tox DNA (tox $\left.x^{-}\right)$might belong to a different pathovar. We therefore conducted a phylogenetic analysis by using partial sequences of the genes for DNA gyrase B subunit $($ gyrB $)$ and $\sigma^{70}$ factor $(r p o D)$ from six representative tox isolates. Both proteins are ubiquitous in bacteria and essential for cell growth and were used previously for phylogenetic analysis of the genus Pseudomonas (53). A total of 534 nucleotides for gyrB and 572 nucleotides for $r p o D$ were identical to the corresponding sequences of four strains each of $P$. syringae pv. phaseolicola and $P$. syringae pv. glycinea (53). The neighbor-joining tree (data not shown) resulting from the analysis of the combined partial gyr $B$ and $r p o D$ sequences was essentially identical to the previously constructed tree (53) and clustered the six tox isolates together with $P$. syringae pv. phaseolicola and $P$. syringae pv. glycinea and well apart from other $P$. syringae pathovars.

ELISA. Because most of the Spanish isolates of $P$. syringae pv. phaseolicola cannot be detected by the currently available PCR protocols, we tested the specificity of other available detection techniques. Isolates were tested by DAS-ELISA using one of the several commercial antibodies available for the detection of $P$. syringae pv. phaseolicola and using two strains of $P$. syringae pv. syringae as negative controls. The polyclonal antibody used reacted as expected with all the isolates that contained the phaseolotoxin gene cluster, producing clear positive reactions, with SR mean values ranging between 82 and 113. Conversely, clear negative reactions were observed for all the tox ${ }^{-}$isolates (mean SR values between 0.2 and 13) and for two P. syringae pv. glycinea (mean SR values of 0 and 3). Our results, therefore, indicate that the Spanish isolates lacking tox DNA cannot be detected using a commercial ELISA test and suggest that other commercial antibodies also might fail to detect this type of $P$. syringae pv. phaseolicola isolate.

Race identification. We wanted to set up a method to allow the rapid identification of races as well as to assess the diversity of races in the sampled area. The previous molecular characterization of $P$. syringae pv. phaseolicola isolates $(7,23)$ appears to indicate that races are polyphyletic, which could make the identification of race-specific molecular markers problematical. We therefore dcided to examine the amplification by PCR of $a v r$ gene bands characteristic of races (Table 1). Selected genes were avrPphB, which is present only in races 3 and 4 (16), avrPphE, producing an amplification product 104 bp larger in race 8 (42), and $\operatorname{avrPphF}$, which is carried only by races $1,5,7$, and 9 (48). From the 138 isolates examined, 108 isolates $(78.3 \%)$ contained gene $a v r P p h F$ and were tentatively assigned to the group of races 1, 5, 7 , and 9 . The remaining 30 isolates $(21.7 \%)$ were tentatively included in races 2 or 6 , because no isolates were found that could be assigned to races 3,4 , or 8 .

The reactions of 89 randomly selected isolates on the bean differentials resulted in a race assignation (Table 4) that widely agreed with the PCR analyses: 51 isolates $(57.3 \%)$ were assigned to races $1,5,7$, and 9, while 21 isolates $(23.6 \%)$ were included in races 2 and 6 . In addition, we found no isolates that corresponded to races 3,4 , or 8 , as was predicted from the PCR results described previously. The $a v r$ gene content of all these isolates, as examined by PCR, was as expected for the race in which they

TABLE 3. Characteristics and identification of 152 Pseudomonas syringae isolates from infected beans in Spain

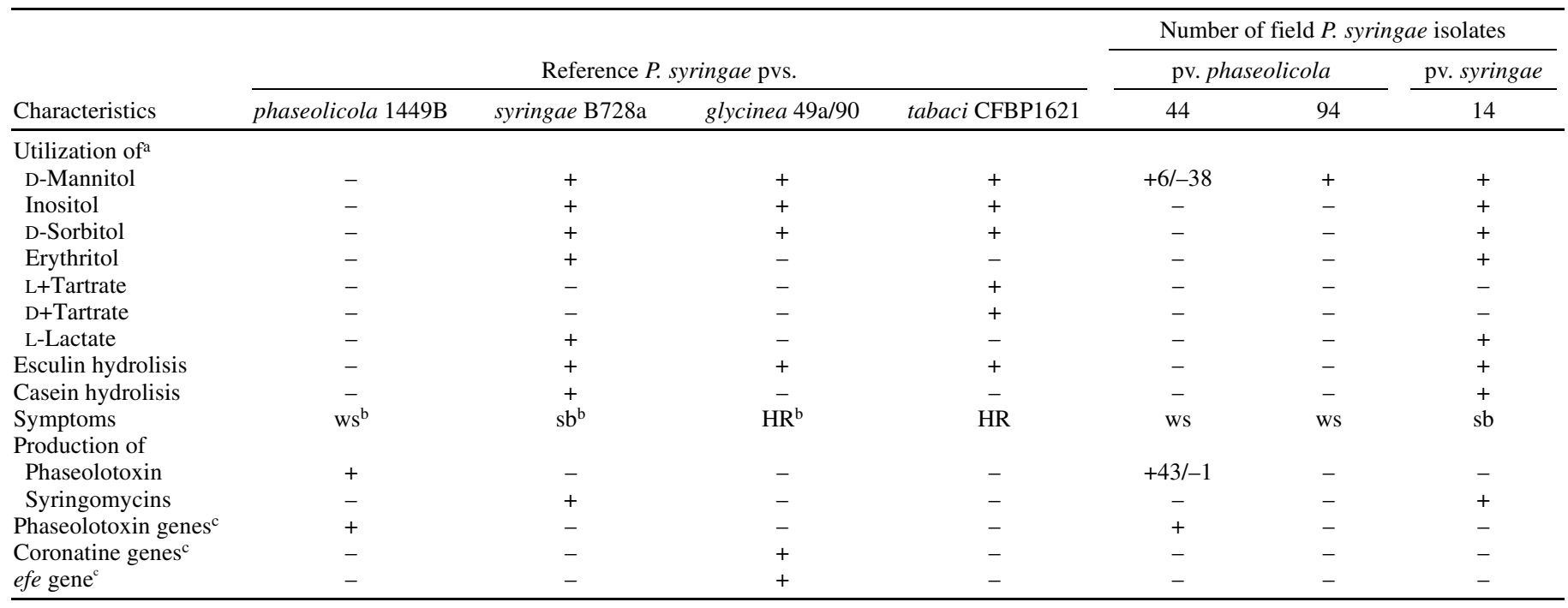

${ }^{a}$ Utilization of compounds as the sole carbon source.

${ }^{\mathrm{b}}$ Symptoms scored 4 days after stab inoculation of pods of the universally susceptible bean cv. Canadian Wonder; ws, water-soaked lesions with occasional bacterial ooze; sb, sunken brown lesions; and HR, hypersensitive reaction.

${ }^{\mathrm{c}}$ Examined by polymerase chain reaction with specific primers. 
were classified by the plant assays (Table 1). However, 17 additional isolates, including 16 tox $x^{-}$isolates that contained $a v r P p h F$, produced sets of reactions that were not compatible with any of the known races. The patterns of these reactions appeared to warrant their classification in at least five new putative races (data not shown).

In general, race 7 was the most abundant (46.1\%) followed by races $6(21.3 \%)$ and $1(9.0 \%)$, while only one or two isolates each were found for races 2, 5, and 9. Noticeably, all the tox ${ }^{-}$isolates contained gene $a v r P p h F$ and, in consequence, the majority of the race 1 and 7 isolates belonged to this group. We did not find any obvious correlation between the race isolated and the place, date, or cultivar of isolation.

\section{DISCUSSION}

We characterized a collection of 152 fluorescent pseudomonads isolated between 1993 and 2001 in north-central Spain from lesions on field-grown common bean landraces. Similar to many other bean-growing regions of the world $(31,41), P$. syringae pv. phaseolicola was the most abundant bacterial pathogen found, representing $91 \%$ of the total isolates, while the remaining were $P$. syringae pv. syringae (Table 3 ). The majority $(68.8 \%)$ of the $P$. syringae pv. phaseolicola isolates did not produce phaseolo-

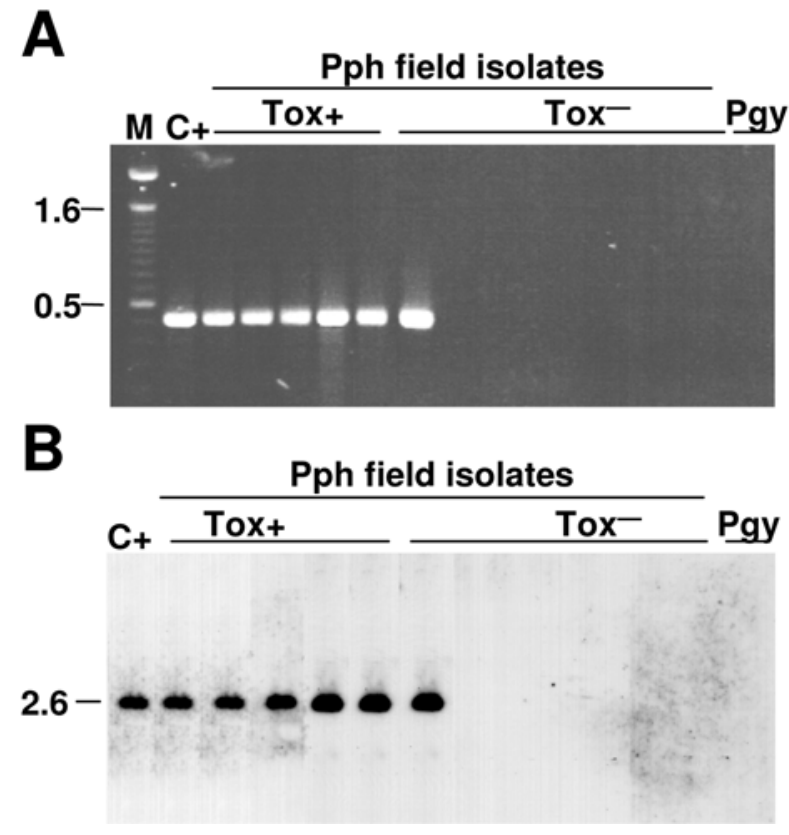

Fig. 1. Detection of a sequence specific for the phaseolotoxin biosynthesis cluster in $\mathrm{Tox}^{+}$and $\mathrm{Tox}^{-}$Spanish field isolates of Pseudomonas syringae pv. phaseolicola (Pph). A, Electrophoretic analysis of polymerase chain reaction amplification products obtained with primer pair $\mathrm{P}$ 5.1-P 3.1, directed to open reading frame 6 from the phtE locus. $\mathrm{C}+, P$. syringae pv. phaseolicola $1449 \mathrm{~B}$ used as a $\mathrm{Tox}^{+}$control; Pgy, $P$. syringae pv. glycinea 49a/90 used as a Tox ${ }^{-}$control; and M, 1-kb marker. B, Southern blot hybridization of genomic DNA digested with EcoRI. The amplicon generated from strain 1449B with primers P 5.1-P 3.1 was cloned, purified, labeled with digoxinenin, and used as a probe. Sizes are indicated to the left in kilobases. toxin (Table 3), which contrasts sharply with the general belief that $\mathrm{Tox}^{+}$isolates are the only ones with epidemiological importance $(30,31,37)$. Additionally, all but one of the nontoxigenic isolates lacked DNA homologous to ORF 6 (Table 2), a putative fatty acid desaturase gene that is essential for the biosynthesis of phaseolotoxin (54). Identification of the tox- as $P$. syringae pv. phaseolicola was unambiguously confirmed by comparison of gyrB and $r p o D$ sequences from six representative tox $x^{-}$isolates to those of other P. syringae pathovars and Pseudomonas spp. (53).

The absence of DNA homologous to ORF 6 in the tox $x^{-}$strains is noteworthy, because the primers used in current PCR protocols for the detection and identification of this pathogen are based on this DNA sequence (37). In a separate study (J. A. Oguiza, A. Rico, L. Rivas, L. Sutra, A. Vivian, and J. Murillo, unpublished data), we showed that strains lacking ORF 6 also lacked DNA homologous to the genes in the known borders of the tox cluster, $\arg K$ and $a m t A$. This suggests that the tox cluster was probably acquired only by some $P$. syringae pv. phaseolicola strains and not by others and indicates the impracticality of using primer sets directed to other regions of the tox cluster for the detection or the identification of this pathogen $(23,25,28)$. Furthermore, a commercial kit for the specific detection of $P$. syringae pv. phaseolicola by DAS-ELISA also failed to detect the Spanish isolates. Because the kit contains a polyclonal antibody, our results suggest the existence of significant differences between the isolates containing the tox cluster and those putatively lacking it and could imply that other commercial antibodies also might fail to detect the tox ${ }^{-}$strains. In support of this, a selection of the tox ${ }^{-}$isolates characterized here did not react with another polyclonal antisera produced against whole-cell preparations of a $\operatorname{Tox}^{+} P$. syringae $\mathrm{pv}$. phaseolicola strain (F. J. Legorburu and I. Ruiz de Galarreta, personal communication). In consequence, it is possible that the certification of seed lots as free of the pathogen cannot be reliably done in Spain, or in any other country where these kinds of strains might occur frequently, using current PCR or serological protocols.

To our knowledge, this is the first report of the widespread occurrence in the field of nontoxigenic $P$. syringae pv. phaseolicola strains. Although very rarely, nontoxigenic isolates are reported in the literature $(37,50)$ and were responsible for the occurrence of some outbreaks of the so-called "halo-less" halo blight in Australia (17). However, even though one of these isolates produced no detectable toxin in the culture medium, the presence in the medium of a trace of phaseolotoxin was established unequivocally (24), indicating that these isolates putatively contained the phaseolotoxin biosynthesis cluster. It is possible that the isolates lacking tox DNA represent the original population of $P$. syringae pv. phaseolicola in Spain. In support of this, since 1987 (1) we have seen a noticeable increase in the number of isolates belonging to the primitive race 2 , which was later divided into races 2,6 , and 8 (45). This increase was particularly noticeable in areas where commercial cultivars were planted, suggesting that this could have contributed to the introduction of these new races. The increase in the frequency of race 6 isolates could be due to their capacity to infect a wider range of bean cultivars or to its capacity to produce phaseolotoxin. However, the predominance of tox isolates is evidence against a role of phaseolotoxin in virulence.

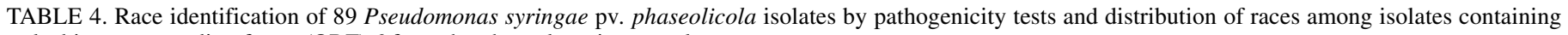
or lacking open reading frame (ORF) 6 from the phaseolotoxin gene cluster

\begin{tabular}{|c|c|c|c|c|c|c|c|c|c|c|c|}
\hline \multirow[b]{2}{*}{ ORF 6} & \multicolumn{10}{|c|}{ Number of isolates per race } & \multirow[b]{2}{*}{ Total } \\
\hline & 1 & 2 & 3 & 4 & 5 & 6 & 7 & 8 & 9 & $?$ & \\
\hline Present & 1 & 2 & 0 & 0 & 0 & 19 & 6 & 0 & 0 & 1 & 29 \\
\hline Absent & 7 & 0 & 0 & 0 & 1 & 0 & 35 & 0 & 1 & 16 & 60 \\
\hline Total & 8 & 2 & 0 & 0 & 1 & 19 & 41 & 0 & 1 & 17 & 89 \\
\hline
\end{tabular}


Indeed, nontoxigenic mutants of $P$. syringae pv. phaseolicola are still pathogenic and their virulence is comparable to that of the wild type $(26,27)$, except that there is no formation of chlorotic haloes; however, there is limited evidence that phaseolotoxin might contribute to systemic movement of bacteria in planta (26). Likewise, phaseolotoxin appears to contribute to the formation of chlorotic halo lesions in kiwifruit canker produced by $P$. syringae pv. actinidiae, but not for production of other symptoms or for the multiplication of the pathogen in planta (43). It is possible however, that the toxin provides an ecological advantage that explains its acquisition by two different pathovars. For instance, because phaseolotoxin inhibits a key metabolic pathway, it is feasible that it might act by inhibiting the growth of potential competitors. Nevertheless, it would be necessary to obtain appropriate experimental evidence to support the role, if any, of phaseolotoxin in virulence.

Race 6 appears to be predominant worldwide $(19,20,45)$; however, more than $78 \%$ of the Spanish isolates contained avrPphF and only $21 \%$ belonged to race 6 . An important asymmetry is that all the tox $x^{-}$isolates contained $a v r P p h F$, whereas the majority of the $\mathrm{Tox}^{+}$isolates lacked it. The prevalence of $\operatorname{avrPphF}$ in the Spanish population is striking and currently difficult to explain. This gene is embedded in a plasmid-borne pathogenicity island (13) and has been shown to increase the virulence of the race 7 isolate 1449B to bean cv. Tendergreen and to different cultivars of soybean (48). Additionally, avrPphF also restricts the host range of the bacterium by inciting a resistance reaction in bean cultivars containing the resistance gene $R l$, such as Red Mexican and Guatemala 196-B. It is then possible that avrPphF was acquired only by certain groups of isolates because it confers a selective advantage, such as increased virulence to the local bean genotypes or to other alternative hosts. Alternatively, avrPphF might have been originally inherited by the ancestor of $P$. syringae pv. phaseolicola and has been selectively lost only by certain isolates. This last possibility is likely taking into account the close phylogenetic relationships of strains containing or lacking tox DNA.

The avr gene content of the individual isolates, as determined by PCR using primer pairs specific for three $a v r$ genes, allowed us to make predictions about the race structure of the native bacterial population that agreed in general with the results obtained by plant assays. This PCR method is valuable in that it determines the existence in the bacterial population of particular $a v r$ genes, which are responsible for specific plant resistance phenotypes that might be of interest to plant breeders. Of the five genes postulated to explain the existence of nine races in $P$. syringae pv. phaseolicola, only three $a v r$ genes were cloned and sequenced (Table 1). Because we used primers to detect only these last three avirulence genes, the method only gives a broad idea of the groups of races present, although it might be used accurately to detect the presence of races 3, 4, and 8, whose distribution is limited. As more avr genes are characterized, the method may be refined to precisely identify each race. In our case, both PCR and plant assays showed a preponderance of isolates containing $a v r P p h F$, which is characteristic of races $1,5,7$, and 9 , and evidenced the absence of isolates belonging to races 3,4 , and 8 . A source of discrepancy that lowered the predictive value of the $a v r$-PCR method was the existence of $19 \%$ of isolates, most of which contained avrPphF, that could not be classified in any of the known races (Table 4). Other researchers have reported the existence of isolates whose race could not be established $(7,20,23,45)$. As these results and ours indicate, it is possible that there are several new, as of yet, uncharacterized races of $P$. syringae pv. phaseolicola. This is further supported (5) by the inconsistencies between reactions observed after leaf and pod inoculation for certain isolates, but not for others, suggesting the existence of new $a v r$ genes or alleles in the $P$. syringae pv. phaseolicola population that could determine new races.

\section{ACKNOWLEDGMENTS}

This work was supported with grant RTA01-005-C2 from the Spanish Instituto Nacional de Investigación y Tecnología Agraria y Alimentaria (INIA). A. Rico was funded by a fellowship from the INIA and R. López was funded by a fellowship from the Consejería de Agricultura y Ganadería, Junta de Castilla y León. We wish to dedicate this publication to F. García-Arenal. We thank C. Manceau, G. W. Sundin, J. Taylor, A. de Vicente, A. Vivian, and M. Ullrich for bacterial and fungal strains, T. Osinga and $\mathrm{T}$. Williams for critically reading the manuscript and for helpful suggestions, and S. Fernández for technical assistance.

\section{LITERATURE CITED}

1. Asensio, C. 1996. Bacteriosis de judías en Castilla y León: Identificación de la variación patogénica de Pseudomonas syringae pv. phaseolicola y factores que influyen en su desarrollo. Estudio de la herencia de la resistencia a la raza 1 de P.s. pv. phaseolicola. Ph.D. thesis. Universidad de León, Spain.

2. Audy, P., Braat, C. E., Saindon, G., Huang, H. C., and Laroche, A. 1996. A rapid and sensitive PCR-based assay for concurrent detection of bacteria causing common and halo blight in bean seed. Phytopathology 86:361-366.

3. Cazorla, F. M. 1998. Pseudomonas syringae pv. syringae, agente causal de la necrosis apical del mango. Ecología y caracterización bacteriológica y molecular. Ph.D. thesis. Universidad de Málaga, Spain.

4. de Andrés, M. F., García-Arenal, F., López, M. M., and Melgarejo, P. 1998. Patógenos de plantas descritos en España. Ministerio de Agricultura, Pesca y Alimentación, Madrid.

5. Fourie, D. 1998. Characterization of halo blight races on dry beans in South Africa. Plant Dis. 82:307-310.

6. Gasson, M. J. 1980. Indicator technique for antimetabolic toxin production by phytopathogenic species of Pseudomonas. Appl. Environ. Microbiol. 39:25-29.

7. González, A. J., Landeras, E., and Mendoza, M. C. 2000. Pathovars of Pseudomonas syringae causing bacterial brown spot and halo blight in Phaseolus vulgaris L. are distinguishable by ribotyping. Appl. Environ. Microbiol. 66:850-854.

8. Goszczynska, T., and Serfontein, J. J. 1998. Milk-Tween agar, a semiselective medium for isolation and differentiation of Pseudomonas syringae pv. syringae, Pseudomonas syringae pv. phaseolicola and Xanthomonas axonopodis pv. phaseoli. J. Microbiol. Methods 32: 65-72.

9. Gross, D. C., and De Vay, S. E. 1977. Production and purification of syringomycin, a phytotoxin produced by a Pseudomonas syringae. Physiol. Plant Pathol. 11:13-28.

10. Harper, S., Zewdie, N., Brown, I. R., and Mansfield, J. W. 1987. Histological, physiological and genetical studies of the responses of leaves and pods of Phaseolus vulgaris to three races of Pseudomonas syringae pv. phaseolicola and to Pseudomonas syringae pv. coronafaciens. Physiol. Mol. Plant Pathol. 31:153-172.

11. Hernández-Guzmán, G., and Alvarez-Morales, A. 2001. Isolation and characterization of the gene coding for the amidinotransferase involved in the biosynthesis of phaseolotoxin in Pseudomonas syringae pv. phaseolicola. Mol. Plant-Microbe Interact. 14:545-554.

12. Innes, N. L., Conway, J., and Taylor, J. D. 1984. Resistance to halo blight in the Cambridge accession V4604 and V4058 of Phaseolus beans. Ann. Appl. Biol. 104:307-314.

13. Jackson, R. W., Athanassopoulos, E., Tsiamis, G., Mansfield, J. W., Sesma, A., Arnold, D. L., Gibbon, M. J., Murillo, J., Taylor, J. D., and Vivian, A. 1999. Identification of a pathogenicity island, which contains genes for virulence and avirulence, on a large native plasmid in the bean pathogen Pseudomonas syringae pathovar phaseolicola. Proc. Natl. Acad. Sci. 96:10875-10880.

14. Jackson, R. W., Mansfield, J. W., Ammouneh, H., Dutton, L. C., Wharton, B., Ortiz-Barredo, A., Arnold, D. L., Tsiamis, G., Sesma, A., Butcher, D., Boch, J., Kim, Y. J., Martin, G. B., Tegli, S., Murillo, J., and Vivian, A. 2002. Location and activity of members of a family of virPphA homologues in pathovars of Pseudomonas syringae and $P$. savastanoi. Mol. Plant Pathol. 3:205-216.

15. Jansing, H., and Rudolph, K. 1990. A sensitive and quick test for determination of bean seed infestation by Pseudomonas syringae pv. phaseolicola. J. Plant Dis. Prot. 97:42-55.

16. Jenner, C., Hitchin, E., Mansfield, J., Walters, K., Betteridge, P., Teverson, D., and Taylor, J. 1991. Gene-for-gene interactions between Pseudomonas syringae pv. phaseolicola and Phaseolus. Mol. PlantMicrobe Interact. 4:553-562.

17. Johnson, J. C. 1969. "Halo-less" halo blight of French bean in Queensland. Queensl. J. Agric. Anim. Sci. 26:293-302. 
18. King, E. O., Ward, N. K., and Raney, D. E. 1954. Two simple media for the demonstration of pyocyanin and fluorescein. J. Lab. Clin. Med. 44:301-307.

19. Kiryakov, I. 2001. Characterization of Pseudomonas syringae pv. Phaseolicola races in North-Eastern Bulgaria. Bulg. J. Agric. Sci. 7:313-318.

20. Lamppa, R. S., Gross, P. L., and del Río, L. E. 2002. Identification of races of Pseudomonas syringae pv. phaseolicola present in North Dakota. (Abstr.) Phytopathology 92(suppl.):S139.

21. Lelliott, R. A., and Stead, D. E. 1987. Methods for the Diagnosis of Bacterial Diseases of Plants, vol. 2. Blackwell Scientific Publications, London.

22. Liyanage, H., Palmer, D. A., Ullrich, M., and Bender, C. L. 1995. Characterization and transcriptional analysis of the gene cluster for coronafacic acid, the polyketide component of the phytotoxin coronatine. Appl. Environ. Microbiol. 61:3843-3848.

23. Marques, A. S. d. A., Corbière, R., Gardan, L., Tourte, C., Manceau, C., Taylor, J. D., and Samson, R. 2000. Multiphasic approach for the identification of the different classification levels of Pseudomonas savastanoi pv. phaseolicola. Eur. J. Plant Pathol. 106:715-734.

24. Mitchell, R. E. 1978. Halo blight of beans: Toxin production by several Pseudomonas phaseolicola isolates. Physiol. Plant Pathol. 13:37-49.

25. Molouba, F., Guimier, C., Berthier, C., Guenard, M., Olivier, V., Baril, C., and Horvais, A. 2001. Detection of bean seed-borne pathogens by PCR. Acta Hortic. 546:603-607.

26. Patil, S. S., Hayward, A. C., and Emmons, R. 1974. An ultravioletinduced non-toxigenic mutant of Pseudomonas phaseolicola of altered pathogenicity. Phytopathology 64:590-595.

27. Peet, R. C., Lindgren, P. B., Willis, D. K., and Panopoulos, N. J. 1986. Identification and cloning of genes involved in phaseolotoxin production by Pseudomonas syringae pv. phaseolicola. J. Bacteriol. 166:1096-1105.

28. Prosen, D., Hatziloukas, E., Schaad, N. W., and Panopoulos, N. J. 1993. Specific detection of Pseudomonas syringae pv. phaseolicola DNA in bean seed by polymerase chain reaction-based amplification of a phaseolotoxin gene region. Phytopathology 83:965-970.

29. Rico, A., López, R., Aizpún, M., Asensio, C., and Murillo, J. 2002. Strains of $P$. savastanoi pv. phaseolicola isolated from diseased beans in Spain cannot be detected using primers directed to the phaseolotoxin gene cluster. Abstract book of the 6th Int. Conf. Pseudomonas syringae Pathovars and Related Pathogens.

30. Rudolph, K. W. E. 1995. Pseudomonas syringae pathovars. Pages 47138 in: Pathogenesis and Host Specificity in Plant Diseases, vol. 1. U. S. Singh, R. P. Singh, and K. Kohmoto, eds. Elsevier Science, Oxford, UK.

31. Saettler, A. W. 1991. Diseases caused by bacteria. Pages 29-32 in: Compendium of Bean Diseases. R. Hall, ed. The American Phytopathological Society, St. Paul, MN.

32. Saitou, N., and Nei, M. 1987. The neighbor-joining method: A new method for reconstructing phylogenetic trees. Mol. Biol. Evol. 4:406-425.

33. Sambrook, J., Fritsch, E. F., and Maniatis, T. 1989. Molecular Cloning: A Laboratory Manual. 2nd ed. Cold Spring Harbor Laboratory, Cold Spring Harbor, NY.

34. Sato, M., Watanabe, K., Yazawa, M., Takikawa, Y., and Nishiyama, K. 1997. Detection of new ethylene-producing bacteria, Pseudomonas syringae pvs. cannabina and sesami, by PCR amplification of genes for the ethylene-forming enzyme. Phytopathology 87:1192-1196.

35. Sawada, H., Takeuchi, T., and Matsuda, I. 1997. Comparative analysis of Pseudomonas syringae pv. actinidiae and pv. phaseolicola based on phaseolotoxin-resistant ornithine carbamoyltransferase gene $(\arg K)$ and 16S-23S rRNA intergenic spacer sequences. Appl. Environ. Microbiol. 63:282-288.

36. Schaad, N. W., Azad, H., Peet, R. C., and Panopoulos, N. J. 1989. Identification of Pseudomonas syringae pv. phaseolicola by a DNA hybridization probe. Phytopathology 79:903-907.

37. Schaad, N. W., Cheong, S. S., Tamaki, S., Hatziloukas, E., and Panopoulos, N. J. 1995. A combined biological and enzymatic amplification (BIO-PCR) technique to detect Pseudomonas syringae pv. phaseolicola in bean seed extracts. Phytopathology 85:243-248.
38. Schaad, N. W., and Frederick, R. D. 2002. Real-time PCR and its application for rapid plant disease diagnostics. Can. J. Plant Pathol. 24:250258.

39. Schaad, N. W., Jones, J. B., and Chun, W. (eds.) 2001. Laboratory Guide for Identification of Plant Pathogenic Bacteria. 3rd ed. The American Phytopathological Society, St. Paul, MN.

40. Siverio, F., Cambra, M., Gorris, M. T., Corzo, J., and López, M. M. 1993. Lipopolysaccharides as determinants of serological variability in Pseudomonas corrugata. Appl. Environ. Microbiol. 59:1805-1812.

41. Smith, I. M., Dunez, J., Lelliot, R. A., Phillips, D. H., and Archer, S. A. 1988. European Handbook of Plant Diseases. Blackwell Scientific Publications, London.

42. Stevens, C., Bennett, M. A., Athanassopoulos, E., Tsiamis, G., Taylor, J. D., and Mansfield, J. W. 1998. Sequence variations in alleles of the avirulence gene avrPphE.R2 from Pseudomonas syringae pv. phaseolicola lead to loss of recognition of the AvrPphE protein within bean cells and a gain in cultivar-specific virulence. Mol. Microbiol. 29:165-177.

43. Tamura, K., Imamura, M., Yoneyama, K., Kohno, Y., Takikawa, Y., Yamaguchi, I., and Takahashi, H. 2002. Role of phaseolotoxin production by Pseudomonas syringae pv. actinidiae in the formation of halo lesions of kiwifruit canker disease. Physiol. Mol. Plant Pathol. 60: 207-214.

44. Taylor, J. D. 1970. Bacteriophage and serological methods for the identification of Pseudomonas phaseolicola (Burkh.) Dowson. Ann. Appl. Biol. 66:387-395.

45. Taylor, J. D., Teverson, D. M., Allen, D. J., and Pastor-Corrales, M. A. 1996. Identification and origin of races of Pseudomonas syringae pv. phaseolicola from Africa and other bean growing areas. Plant Pathol. 45:469-478.

46. Thompson, J. D., Gibson, T. J., Plewniak, F., Jeanmougin, F., and Higgins, D. G. 1997. The ClustalX windows interface: Flexible strategies for multiple sequence alignment aided by quality analysis tools. Nucleic Acids Res. 25:4876-4882.

47. Tourte, C., and Manceau, C. 1995. A strain of Pseudomonas syringae which does not belong to pathovar phaseolicola produces phaseolotoxin. Eur. J. Plant Pathol. 101:483-490.

48. Tsiamis, G., Mansfield, J. W., Hockenhull, R., Jackson, R. W., Sesma, A., Athanassopoulos, E., Bennett, M. A., Stevens, C., Vivian, A., Taylor, J. D., and Murillo, J. 2000. Cultivar specific avirulence and virulence functions assigned to avrPphF in Pseudomonas syringae pv. phaseolicola, the cause of bean halo-blight disease. EMBO J. 19:3204-3214.

49. Vivian, A., Gibbon, M. J., and Murillo, J. 1997. The molecular genetics of specificity determinants in plant pathogenic bacteria. Pages 293-328 in: The Gene-for-Gene Relationship in Plant Parasite Interactions. I. R. Crute, E. B. Holub, and J. J. Burdon, eds. CAB International, Wallingford, UK.

50. Völksch, B., and Weingart, H. 1997. Comparison of ethylene-producing Pseudomonas syringae strains isolated from kudzu (Pueraria lobata) with Pseudomonas syringae pv. phaseolicola and Pseudomonas syringae pv. glycinea. Eur. J. Plant Pathol. 103:795-802.

51. Vuurde, J. W. L., and van den Bovenkamp, G. W. 1989. Detection of Pseudomonas syringae pv. phaseolicola. Pages 30-40 in: Detection of Bacteria in Seed and Other Planting Material. A. W. Saettler, N. W. Schaad, and D. A. Roth, eds. The American Phytopathological Society, St. Paul, MN.

52. Weingart, H., and Völksch, B. 1997. Ethylene production by Pseudomonas syringae pathovars in vitro and in planta. Appl. Environ. Microbiol. 63:156-161.

53. Yamamoto, S., Kasai, H., Arnold, D. L., Jackson, R. W., Vivian, A., and Harayama, S. 2000. Phylogeny of the genus Pseudomonas: Intrageneric structure reconstructed from the nucleotide sequences of $g y r B$ and $r p o D$ genes. Microbiology 146:2385-2394.

54. Zhang, Y. X., and Patil, S. S. 1997. The phtE locus in the phaseolotoxin gene cluster has ORFs with homologies to genes encoding amino acid transferases, the AraC family of transcriptional factors, and fatty acid desaturases. Mol. Plant-Microbe Interact. 10:947-960. 